\title{
Transformations in Music Booking
}

Analysing Professional and Subfield Autonomy Together

Les transformations de la programmation musicale. Analyser ensemble

autonomie professionnelle et autonomie d'un sous-champ

Las transformaciones de la programación musical. Analizar conjuntamente

autonomía profesional y autonomía de un sub-campo

\section{Myrtille Picaud}

Translator. Daniela Ginsburg

\section{(2) OpenEdition}

12 Journals

\section{Electronic version}

URL: http://journals.openedition.org/bssg/332

DOI: $10.4000 /$ bssg.332

ISSN: 2490-9424

\section{Publisher}

Presses universitaires de Vincennes

\section{Electronic reference}

Myrtille Picaud, "Transformations in Music Booking", Biens Symboliques / Symbolic Goods [Online], 4 I 2019, Online since 27 June 2019, connection on 04 March 2021. URL: http://journals.openedition.org/ bssg/332 ; DOI: https://doi.org/10.4000/bssg.332 


\section{Les transformations de la programmation musicale}

\section{Analyser ensemble autonomie professionnelle} et autonomie d'un sous-champ
Transformations in Music Booking

Analysing Professional and Subfield

Autonomy Together

\author{
Myrtille Picaud \\ traduction | translation \\ Daniela Ginsburg
}

\begin{abstract}
L'autonomie a été analysée comme l'une des caractéristiques centrales de certaines professions dans leurs concurrences avec d'autres groupes (Freidson 1975). Elle est définie ici par le monopole sur une activité, la définition de son périmètre et du sens qui lui est donné, dans le cadre de luttes autour de l'institutionnalisation du travail d'expertise entre différents groupes professionnels ${ }^{1}$. L'ouvrage consacré par les chercheur.e.s Valérie Boussard, Didier Demazière et Philip Milburn à l'injonction au professionnalisme (2010) interroge les conséquences de la pression des valeurs du marché sur l'autonomie professionnelle, éclairant leurs variations selon le contexte, les caractéristiques du groupe professionnel et sa position au sein de configurations professionnelles. Les professions se positionnent ainsi par rapport à d'autres formes d'organisation occupationnelle en se distinguant des logiques de bureaucratisation et de marché (Freidson 2001), autonomie par rapport à la sphère économique revendiquée par des professions libérales affirmant leur désintéressement par exemple (Karpik 1995 ; Sapiro 2006).
\end{abstract}

1. On s'appuie ici sur les réflexions proposées par Andrew Abbott et son concept de développement professionnel (1988).
Autonomy has been analysed as one of the central features of certain professions in their competition with other groups (Freidson 1975). Here, autonomy is defined in terms of a group's monopoly over a professional activity, the definition of that activity's perimeter, and the meaning given to it, within the framework of struggles between different professional groups over the institutionalization of specialist work ${ }^{1}$. The book by the researchers Valérie Boussard, Didier Demazière and Philip Milburn (2010) on the injunction to professionalize examines how the pressure of market values affects professional autonomy and sheds light on variations in terms of context, the characteristics of the professional group, and its position within professional configurations. Distinguishing themselves from the logics of bureaucratization and of the market (Freidson 2001), professions position themselves in relation to other forms of occupational organization: for example, the "liberal professions" claim to be autonomous from the economic sphere, thus affirming their disinterestedness (Karpik 1995, Sapiro 2006).

1. Here I draw on the reflections proposed by Andrew Abbott and his concept of professional development (1988). 
Cet article poursuit l'analyse des relations entre autonomie professionnelle et contraintes marchandes, en s'appuyant sur une perspective en termes de champ (Bourdieu 1992). Si la notion de champ est sous-tendue par une forme de division du travail et de spécialisation d'un espace social, elle s'appuie également sur un critère d'autonomie, que l'on appellera ici structurelle. L'autonomisation d'un champ s'adosse à la création d'instances de consécration spécifiques, au développement d'un marché des biens symboliques (Bourdieu 1971) mais aussi à l'affirmation d'un groupe de spécialistes. Dans les champs culturels, ce groupe n'est pas toujours doté d'un statut juridique ou de protections spécifiques lui conférant une « autonomie institutionnelle » (Boussard, Demazière, Milburn 2010), qui se distingue donc de l'autonomie structurelle. Cependant, la question posée ici n'est pas celle des groupes professionnels concourant à l'autonomisation d'un champ, mais plutôt des liens unissant l'autonomie structurelle d'un champ et l'autonomie d'un groupe professionnel existant. L'une est-elle la condition de l'autre?

La question de l'autonomie par rapport au champ économique est particulièrement saillante au sein des champs artistiques (Bourdieu 1992). De surcroît, si les professions artistiques posent un défi à la sociologie des professions (Freidson 1986), l'étude de leurs intermédiaires est particulièrement heuristique afin d'interroger les liens entre champs économique et artistique, puisqu'ils font figure d'agents doubles à la frontière de l'art et du commerce (Lizé, Naudier, Roueff 2011 ; Negus 2002), voire sont vecteurs de processus d'hétéronomisation (Lizé \& Naudier 2015). L'étude des salles de musique et leurs programmateurs et programmatrices, dont il sera question ici, permet d'interroger l'interaction entre autonomie structurelle et autonomie professionnelle. Le questionnement sera ainsi décalé du champ musical à l'échelle d'un sous-champ, celui
This article extends analysis of the relations between professional autonomy and market constraints based on a perspective in terms of field (Bourdieu 1996). While the notion of field is underpinned by a form of division of labour and the specialization of a social space, it also relies on a criterion of autonomy, which I will refer to as "structural autonomy." The autonomization of a field is based on the creation of specific consecrating bodies, the development of a market for symbolic goods (Bourdieu 1985), and the proclaimed existence of a group of specialists. In the cultural fields, such groups are not always endowed with a legal status or specific protections that would grant them "institutional autonomy" (Boussard, Demazière, Milburn 2010), which is thus different from structural autonomy. However, the question posed here is not how professional groups contribute to the autonomization of a field, but rather how the structural autonomy of a field is connected to the autonomy of an existing professional group. Is one the condition of the other?

The question of autonomy in relation to the economic field is particularly salient within artistic fields (Bourdieu 1996). Moreover, if the artistic professions pose a challenge to the sociology of professions (Freidson 1986), studying their intermediaries is particularly heuristic for examining the connections between the economic and artistic fields since these intermediaries appear as double agents at the border of art and commerce (Lizé, Naudier, Roueff 2011; Negus 2002), or even as vectors of processes of heteronomy (Lizé \& Naudier 2015). Studying music venues and their bookers makes it possible to analyse the interactions between structural and professional autonomy. The analysis will thus be shifted from the music field to the level of a subfield: that of music venues. Larissa Buchholz's reflections (2016) on the transposition of the concept of field from a local or national to a 
des salles de musique. Les réflexions de Larissa Buchholz (2016) sur la transposition du concept de champ d'une échelle locale ou nationale à une échelle globale ${ }^{2}$ offrent une piste intéressante afin de théoriser les liens entre ces deux niveaux. À propos de la constitution d'un champ global de l'art et du lien avec des champs nationaux préexistants, elle développe ainsi la notion d'« autonomie verticale ». Celle-ci se distingue d'une autonomie horizontale entre des champs nationaux, artistique et économique par exemple. Le terme vertical ne présuppose toutefois pas de hiérarchisation entre les deux niveaux, l'autonomie relative pouvant être analysée dans un sens ou l'autre, par la réfraction des enjeux d'un champ national dans un champ global ou vice versa.

On étudiera donc ici les sous-champs des salles de musique dans deux capitales européennes, Paris et Berlin. Ces sous-champs comprennent les lieux de spectacle et le système d'intermédiation (Jeanpierre \& Roueff 2014) lié à la musique dite live, mais pas les artistes. Jouissant d'une autonomie relative par rapport au champ musical, ces sous-champs circonscrivent un espace de concurrence spécifique pour la production d'une offre de musique "vivante ». La délimitation géographique constitue un espace relationnel, dans lequel les agents, s'ils n'interagissent pas toujours directement, se situent les uns par rapport aux autres. Ils sont positionnés dans cet espace relationnel en fonction de la distribution des différentes sortes de capitaux et rivalisent ou coopèrent pour accumuler du capital symbolique. Quant au champ musical, il est constitué par différentes catégories d'agents (artistes, intermédiaires) et peut être considéré comme transnational. En effet, la création et la reconnaissance de la valeur musicale s'adossent à des processus qui dépassent les frontières nationales. Les diverses formes de

2. Voir aussi à ce propos les réflexions de Gisèle Sapiro sur les champs transnationaux (2013). global scale ${ }^{2}$ offer an interesting way of theorizing the links between these two levels. Focusing on the constitution of a global field of art and its connection to pre-existing national fields, she develops the notion of "vertical autonomy." This notion differs from the horizontal autonomy between national fields, such as the artistic and economic fields. The term "vertical," however, does not presuppose a hierarchy between the two levels, for relative autonomy can be analysed in either direction, in terms of the refraction of the stakes of a national field in a global field or vice versa.

Here, I will study the subfields of music venues in two European capitals, Paris and Berlin. These subfields include the venues and systems of intermediation (Jeanpierre \& Roueff 2014) connected to live music, but not artists. These subfields, which enjoy relative autonomy in the music field, circumscribe a specific space of competition for the production of live music. Geographical delimitation creates a relational space in which agents, though they do not always interact directly, are situated in relation to each other. They are positioned in this relational space according to the distribution of different kinds of capital, and compete or cooperate to accumulate symbolic capital. As for the music field, it is made up of different categories of agent (artists, intermediaries) and can be considered transnational. Indeed, the creation and recognition of music value is based on processes that transcend national boundaries. The various ways in which genres circulate transnationally ${ }^{3}$ remind us that artists and intermediaries often

2. See also Gisèle Sapiro's reflections on transnational fields (2013).

3. See, for example, Motti Regev's analysis of "pop-rock" (2013). 
circulation transnationale des genres ${ }^{3}$ rappellent que les artistes et intermédiaires se réfèrent souvent aux centres dominants, se plient à leurs règles du jeu musical ou tentent de les infléchir

Les rapports de force au sein du champ musical transnational sont aujourd'hui modifiés par les mutations du secteur de la musique live. En effet, avec l'effondrement des profits de l'industrie du disque $^{4}$, le live, secteur économique longtemps considéré comme secondaire, est réinvesti à mesure que les revenus liés à cette activité augmentent depuis la moitié des années 2000. Certains économistes évoquent l'autonomisation du marché de la musique vivante par rapport à celui de la musique enregistrée (Holt 2010 ; Krueger $2005: 26$ ). L'essor des festivals de musique exemplifie l'importance économique et sociale renouvelée de l'événement musical (Frith 2007). Des acteurs centraux du champ musical transnational (majors) rachètent ainsi des entreprises spécialisées dans l'événementiel alors que d'autres acteurs musicaux émergent et leur font concurrence, comme l'entreprise Live Nation. Cette concentration économique permettant des formes d'intégration verticale (contrôle de la chaîne de production musicale jusqu'aux tournées) participe à la montée d'intérêts économiques. L'investissement croissant d'agents du champ économique (fonds de pension, etc.) dans l'événementiel en témoigne également.

Les enjeux liés à ces transformations sont réfractés de façon inégale au sein des sous-champs des salles de musique à Paris et Berlin, dont il sera question dans cet article. Dans ce contexte, nous examinerons leur autonomie structurelle, notamment par rapport

3. Voir, par exemple, l'analyse de Motti Regev à propos du « pop-rock » (2013).

4. Le chiffre d'affaire de l'industrie musicale dans le monde est passé de 25,1 milliards de dollars en 2002 à 16,1 milliards de dollars en 2016. Source Statista : [en ligne] [consulté le 30 août 2017] refer to dominant centres, bend to the rules that govern music for them, or try to influence them.

Today, the balance of power within the transnational music field is being altered by changes in the live music sector. Indeed, with the collapse of profits in the record industry, ${ }^{4}$ this sector, long considered secondary, has been reinvigorated as revenues increased beginning in the mid-2000s. Some economists refer to the autonomization of the live music market with respect to that of recorded music (Holt 2010; Krueger 2005: 26). The rise of music festivals exemplifies the renewed economic and social importance of music events (Frith 2007). Central actors in the transnational music field ("majors") buy companies specializing in event organization while other actors, such as the company Live Nation, emerge and compete with them. This economic concentration, which allows for forms of vertical integration (controlling music production from recording to touring) contributes to the rise of economic interests. Increasing investment in live events by agents from the economic field (pension funds, etc.) also testifies to this.

The stakes of these transformations are unevenly refracted within the subfields of the music venues in Paris and Berlin that will be the focus of this article. In this context, I will examine their structural autonomy-particularly in relation to the economic field-as well as how these changes affect the professional autonomy of live music bookers. The study shows that structural and professional

4. Global music industry turnover has grown from $\$ 25.1$ billion in 2002 to $\$ 16.1$ billion in 2016. Source: Statista [accessed on 30 August 2017] 
au champ économique, et la façon dont ces mutations influent sur l'autonomie professionnelle des programmateur.trice.s. L'enquête montre qu'autonomie structurelle et autonomie professionnelle ne vont pas nécessairement de pair. Les sous-champs des salles de musique à Paris et Berlin sont d'abord présentés, ce qui montre les différentes formes du développement professionnel de la programmation et les variations des situations économique et politique locales. À Paris, l'hétéronomie croissante du sous-champ musical est facilitée par le fort développement professionnel des programmateur-trice-s. Toutefois, cette hétéronomisation semble menacer en retour l'autonomie des programmateur.trice.s, les poussant à redéfinir leur activité, comme nous le verrons dans une deuxième section. L'article s'achève en examinant la situation berlinoise, qui éclaire quant à elle les conditions de possibilité de l'autonomie d'un sous-champ de la musique vivante dont l'économie est moins développée, l'autonomie des programmateurs apparaissant limitée par le plus faible développement professionnel.

\section{Méthodologie}

Le matériau empirique présenté ici est issu d'une recherche mobilisant 56 entretiens, réalisés à Paris et Berlin entre 2012 et 2016 avec des programmateurs et programmatrices de salles de musique de tous types (amphithéâtres, bar musicaux, cabarets, maisons d'opéra ou boîtes de nuit, etc.). Ces entretiens portaient sur le fonctionnement de la salle, son histoire, le travail de programmation et les trajectoires des enquêté $\cdot e \cdot s$. À la demande de la plupart des enquêté $\cdot e \cdot s$, ils·elles sont pseudonymisé $\cdot e \cdot s$. Les entretiens sont complétés par environ 220 observations de concerts dans les deux villes. Dans les deux villes, la représentation de la diversité des salles dans les entretiens a été contrôlée grâce à ma connaissance de l'espace musical et à deux bases de données dans lesquelles je recense de autonomy do not necessarily go hand in hand. First, I will present the music venue subfields in Paris and Berlin, focusing on different forms of professional development for bookers and variations in local economic and political circumstances. In Paris, the growing heteronomy of the music subfield is facilitated by the strong professional development of bookers. However, in return, this heteronomy seems to threaten bookers' autonomy, pushing them to redefine their activity, as will be shown in the second section. The article concludes by examining the situation in Berlin, which sheds light on the conditions of possibility of autonomy for a subfield of live music with a less developed economy, where bookers' autonomy appears to be limited by weaker professional development.

\section{Note on Methodology}

The empirical material presented here was gathered over the course of fifty-six interviews conducted in Paris and Berlin between 2012 and 2016 with bookers at music venues of all types (amphitheatres, music bars, cabarets, opera houses, nightclubs, etc.). The interviews focused on the history and organization of venues, programming work, and the career trajectories of the interviewees. At the request of most respondents, pseudonyms have been used. The interviews are complemented by about 220 observations of concerts in both cities. For both cities, I ensured that the diversity of venues was represented in the interviews by drawing on my knowledge of the music space and two databases in which I exhaustively list the city's venues (on Paris, see Picaud 2015). The comparability of 
façon exhaustive les salles de la ville (à propos de Paris, voir Picaud 2015). La comparabilité des données a également été vérifiée entre les deux souschamps musicaux, en tenant compte de leurs différences structurelles. Cet article se focalise sur les salles privées, les plus nombreuses à Paris et Berlin, même si quelques-unes perçoivent des subventions publiques ponctuelles. Au regard de la problématique étudiée, la distinction public/ privé apparaît plus clivante que l'opposition entre musiques dites savantes et populaires, les salles de musiques classiques privées étant également touchées par les mutations en cours dans la musique vivante.

Parmi les programmateur-trice $s$ rencontrée. $s$ à Paris et Berlin, autour de la moitié travaille dans une salle ouverte après 1996. Lessalles les plusanciennes (avant 1980) représentent respectivement un dixième et un cinquième des lieux enquêtés. Cette répartition est cohérente avec celle de l'ensemble des salles dans les deux villes. Les salles de petite jauge sont plus nombreuses dans les deux capitales, et ont aussi été davantage enquêtées (environ la moitié des personnes interrogées travaille dans une salle de 300 places ou moins) que les plus grandes (autour d'un quart des enquêté e-s travaille pour un lieu de 1000 places ou plus), qui comprennent tant de grandes boîtes de nuit que des lieux tels la Mercedes Benz Arena. Les enquêté e.s officient principalement dans des salles privées aux statuts divers (18 enquêté·e.s à Berlin contre 16 à Paris), dominantes dans l'ensemble, les salles publiques étant elles moins nombreuses à Berlin qu'à Paris (2 enquêté.e-s à Berlin et 4 à Paris) à l'inverse des lieux privés mais associatifs ( 9 enquêté.e.s contre 5 à Paris). Finalement, un peu moins d'un tiers des salles enquêtées ( 9 salles dans chaque ville) programme des musiques « savantes " (classique, lyrique, musique contemporaine), desquelles on distingue le jazz (2 à Berlin et 4 à Paris) et les musiques " populaires ", dans lesquelles sont compris l'ensemble des autres genres observés (26 à Berlin et 21 à Paris), certaines salles étant à cheval entre ces catégories. the data between the two music subfields was also verified, taking into account their structural differences. This article focuses on private venues, which are the most common type of venue in Paris and Berlin, even though some of them receive occasional public subsidies. In view of the issue in question, the public/private distinction appears to be more significant than the opposition between so-called "highbrow" music and "lowbrow" or "popular" music, since private classical music halls are also affected by the changes occurring in live music.

Of the bookers I met in Paris and Berlin, about half work in venues that were opened after 1996. Older venues (those that opened before 1980) represent one-tenth and one-fifth of those surveyed respectively. This distribution is consistent with that of all venues in both cities. Smaller venues are more numerous in both capitals, and were studied more (about half of the bookers interviewed work in venues with 300 seats or less) than larger ones (around a quarter of the respondents work for venues with capacity for 1,000 or more), which include both large nightclubs and venues such as the Mercedes Benz Arena. The respondents work mainly in private venues, which dominate the study (eighteen in Berlin and sixteen in Paris), and have various statuses; there are fewer public venues in Berlin than in Paris (two in Berlin and four in Paris), in contrast to private, non-profit venues (nine in Berlin versus five in Paris). Finally, a little less than one third of the venues surveyed (nine in each city) host "highbrow" music (classical, lyrical, or contemporary music), from which I distinguish jazz (two venues in Berlin and four in Paris) and "popular" music, which includes all the other genres observed (twenty-six in Berlin and twenty-one in Paris); some venues straddle these categories. 


\section{Développement professionnel de la programmation dans deux sous-champs des salles de musique contrastés}

Avant d'examiner les conditions de l'autonomie de chaque sous-champ des salles de musique, et les implications de celleci pour l'autonomie professionnelle des programmateurs et programmatrices, il importe de souligner les différences entre les deux capitales. Effectivement, à Paris et Berlin, le développement professionnel de la programmation varie (Picaud 2017), tout comme la position occupée par les programmateurs dans le système d'intermédiation. Ces différences sont aussi liées à l'histoire et

l'économie de chaque ville.

À Paris, le développement professionnel est important chez les programmateur.trice.s, dont le monopole sur la sélection des artistes est relativement stable. Quoique les frontières du groupe professionnel demeurent peu formalisées, l'entre-soi permet le contrôle de l'accès aux positions, comme dans d'autres secteurs musicaux (Coulangeon 1999). La plupart des programmateur.trice.s de salles de concert exercent de façon professionnalisée, en dehors des bars musicaux dont la programmation est souvent assurée par les gestionnaires du débit de boissons. À l'exception de ces derniers, la très grande majorité est salariée par la salle de spectacle et une minorité est constituée d'indépendants. $73 \%$ des salles sont privées, auxquelles s'ajoutent $10 \%$ qui ont un statut privé mais associatif. $8 \%$ des salles parisiennes ont un statut public. À Berlin, le groupe des programmateur.trice-s est moins structuré et plus hétérogène. Les réseaux entre professionnel-le·s sont moins denses et leurs statuts sont variables : indépendant $\cdot e \cdot s$, plus rarement salarié $\cdot e \cdot s$, et non déclaré $\cdot e \cdot s$. Par ailleurs, une part non négligeable de salles pourtant reconnues sont programmées par

\section{Professional Development for Booking in Two Contrasting Subfields of Music Venues.}

Before examining the conditions of autonomy in each subfield of music venues and the implications this has for bookers' professional autonomy, it is important to highlight the differences between the two capital cities. Professional development of bookers is different in Paris and in Berlin (Picaud 2017), as is the position this role holds in the system of intermediation. These differences are also related to the history and economy of each city.

In Paris, professional development is high for bookers, whose monopoly over artist selection is relatively stable. Although the boundaries of the professional group are not well formalized, strong ties between intermediaries allow the group to control access to jobs, as is the case in other music sectors (Coulangeon 1999). Most concert venue bookers are professionals, except in music bars, where bar managers often schedule music acts. With the exception of the latter, who own their bars, the vast majority are employed by the venue while a minority are independent contractors. Seventythree per cent of the venues are private, and another ten per cent have private though non-profit status. Eight per cent of Parisian venues have public status. In Berlin, the professional group of bookers is less structured and more heterogeneous. Networks between professionals are less dense and their statuses are variable: they are often independent contractors, more rarely salaried employees, and may work under the table. In addition, a significant proportion of well-respected venues are booked by volunteers. Private venues represent seventy-six per cent of 
des personnes bénévoles. Les salles privées représentent $76 \%$ de l'ensemble, auxquels s'ajoutent $15 \%$ de salles associatives. Les salles publiques représentent seulement $4 \%$ de l'échantillon

et $7 \%$ ont un statut inconnu ( $6 \%$ à Paris).

La non-rémunération d'une activité malgré tout envisagée comme principale est particulièrement présente dans la capitale allemande. Si à Paris une part importante parmi la trentaine de programmateurs et programmatrices enquêté $\cdot$ es fait état d'une activité exercée en parallèle (en dehors de faire soi-même de la musique), cela relève moins de la nécessité matérielle que de la norme professionnelle de la pluriactivité (Lizé 2014 ; Bureau, Perrenoud, Shapiro 2009). Celle-ci permet de cumuler les bénéfices liés à différentes positions dans les champs culturels et d'accroître son capital social. Au contraire, à Berlin, la polyactivité en dehors du champ musical permet souvent de subvenir aux besoins matériels de personnes ne vivant pas de leur activité de programmation. Alors que dans la capitale française seules trois personnes parmi les 26 interrogées ne vivent pas de la programmation, cette situation concerne plus d'un tiers des 30 personnes rencontrées à Berlin et ce, quelle que soit la catégorie d'âge - il ne s'agit pas d'une difficulté des plus jeunes à s'insérer sur le marché de l'emploi.

II n'est pas rare que les salles berlinoises soient programmées par des collectifs de taille variable, permettant de concilier activité rémunérée et programmation. Cette organisation, qui concerne un tiers des salles enquêtées, donne le plus souvent lieu à une division du travail temporelle, en fonction des événements organisés, plutôt que selon les tâches prises en charge, puisque les membres des collectifs peuvent prendre part à la programmation, mais aussi à la billetterie, la tenue du bar, etc. À Paris, la division du travail est plus stabilisée, même si la programmation peut être divisée selon les genres ou adjointe à la communication et/ou à la production the total, plus fifteen per cent non-profit venues. Public venues represent only four per cent of the sample and seven per cent have unknown status (versus six per cent in Paris)

Non-remuneration of booking, an activity that is nevertheless considered someone's primary form of work is particularly common in the German capital. Although in Paris a significant proportion of the thirty or so bookers surveyed reported a professional activity carried out in parallel (apart from making music themselves), this is less a matter of material necessity than a professional standardit is expected that people working in the live music field will hold multiple jobs related to music (Lizé 2014; Bureau, Perrenoud, Shapiro 2009). This allows them to accumulate the benefits connected to different positions in the cultural fields and to increase their social capital. On the contrary, in Berlin, having multiple jobs outside the music field often allows bookers to meet their material needs. Whereas in the French capital, only three of the twenty-six people interviewed do not live off their booking work, more than a third of the thirty interviewed in Berlin do not, regardless of age category -it is not simply an issue of young people having a hard time entering the job market.

It is not uncommon for the Berlin venues to be programmed by collectives of varying sizes, which allows members to pursue paid work alongside booking. This type of organization, which is found in a third of the venues surveyed, usually gives rise to a temporal division of labour; that is, division by event, rather than by task, since the members of the collectives may participate in programming and also work the ticket office, the bar, etc. In Paris, the division of labour is more stable, although programming may be divided on the basis of music genre or combined with public relations and/or 
dans les petites salles. L'organisation collective à Berlin participe à l'élargissement du recrutement social des individus accédant à la programmation, ce que reflète la diversité de leurs trajectoires sociales et scolaires. Un cinquième seulement a suivi des études de gestion ou de management culturel, alors qu'à Paris les écoles de commerce et études de gestion concernent la moitié des enquêté $\cdot \mathrm{e} \cdot \mathrm{s}$ et le management culturel un petit quart. De manière plus générale, la clôture du groupe chez les programmateurs et programmatrices à Berlin est moindre, car les droits d'entrée (Mauger 2007) sont plus faibles. Il est plus facile d'ouvrir une salle, même si le lieu choisi n'est ni destiné ni adapté aux conditions de sécurité, sonores, d'accueil du public, etc. Les contrôles du respect des normes sont moins fréquents qu'à Paris, comme le montrent des fermetures spectaculaires, après plusieurs années d'activité, de salles qui dérogeaient totalement aux dispositions réglementaires

(le complexe culturel Stattbad Wedding par exemple).

Le faible prix de l'immobilier facilite l'ouverture de salles dans des lieux non dédiés à la musique, alors qu'à Paris le rachat ou le changement de direction de salles déjà occupées est plus fréquent. À titre d'exemple, le prix du mètre carré en location privée varie entre 20 et 30 euros en moyenne selon les arrondissements, contre 5 à 10 euros dans la capitale allemande. Ce contraste s'inscrit plus généralement dans des économies très différentes, dont témoigne le niveau de vie des populations. Alors qu'en 2012 le produit intérieur brut $(\mathrm{PIB})$ par habitant·e à Paris est supérieur de $64 \%$ à la moyenne nationale, Berlin est l'une des rares capitales européennes où il est inférieur à la moyenne nationale (de $16 \%$ ). Corroborant le fait précédent, l'indice de volume du PIB par habitante est effectivement de 141,5 milliards de standards de pouvoir d'achat (SPA) à Berlin, contre 555,3 à Paris (Koceva et al. 2016 : 98). Cette différence de niveau de vie a des implications pour chaque sous-champ musical, en favorisant ou production work in small venues. In Berlin, collective organization contributes to broadening the social recruitment of individuals to the booking profession, a fact reflected in the diversity of their social and academic trajectories. Only one-fifth have studied management or cultural management, whereas in Paris, half of those surveyed came from business schools or management studies and a quarter have backgrounds in cultural management. More generally, the booker group in Berlin is less closed, because entry cost to the field is lower (Mauger 2007). It is easier to open a venue in Berlin, even if the chosen location is neither intended for that purpose nor adapted to security, sound, and public access requirements, etc. Verification of compliance with standards is less frequent than in Paris, as demonstrated by the spectacular closures, after several years of activity, of venues that had completely deviated from regulatory provisions (the Stattbad Wedding cultural complex, for example).

In Berlin, the low price of real estate facilitates the opening of venues in places not dedicated to music, while in Paris new ownership or change of management of venues already occupied is more common. For example, in Paris, the price per square metre for a private rental ranges between 20 and 30 euros on average depending on the district, versus 5 to 10 euros in the German capital. This contrast is part of a more general difference between the economies of the two cities, which is reflected in the standards of living of their residents. Whereas in 2012, GDP per capita in Paris was $64 \%$ above the national average, Berlin is one of the few European capitals where it is lower than the national average (16\%). Similarly, the GDP per capita volume index is effectively 141.5 billion purchasing power standards (PPS) in Berlin, versus 555.3 billion in Paris (Koceva et al. 2016: 98). This difference in standards of living has implications for each music subfield, by favouring, or not, the 
non le développement d'un marché de la musique live. Si à Paris le prix des places tend à être relativement élevé dans les salles de concert, à Berlin les billets sont moins chers pour des salles équivalentes et, même en faisant abstraction des bars musicaux, il n'est pas rare que l'entrée soit gratuite ou à prix libre. De même, les cachets des artistes sont généralement plus faibles dans la capitale allemande, conduisant certain'e.s d'entre eux·elles à éviter de s'y produire, selon plusieurs de nos enquêté·e·s. Par exemple, un artiste renommé de noise états-unien percevait un cachet presque trois fois supérieur au Point éphémère (salle de musiques actuelles soutenue par la mairie de Paris) qu'à Urban Spree, salle équivalente mais ne bénéficiant pas de soutien public. development of a market for live music. While in Paris, ticket prices tend to be relatively high in concert halls, tickets are cheaper for equivalent venues in Berlin and, even excluding music bars, it is not uncommon for entry to be free or flexible (patrons pay as much or as little as they like). Similarly, artists are usually paid less in the German capital, leading some of them to avoid performing there, according to several of my interviewees. For example, a renowned artist of American noise music was paid almost three times more at Point éphémère (a popular music venue that receives support from the City of Paris) than at Urban Spree, an equivalent venue in Berlin that does not receive public support.

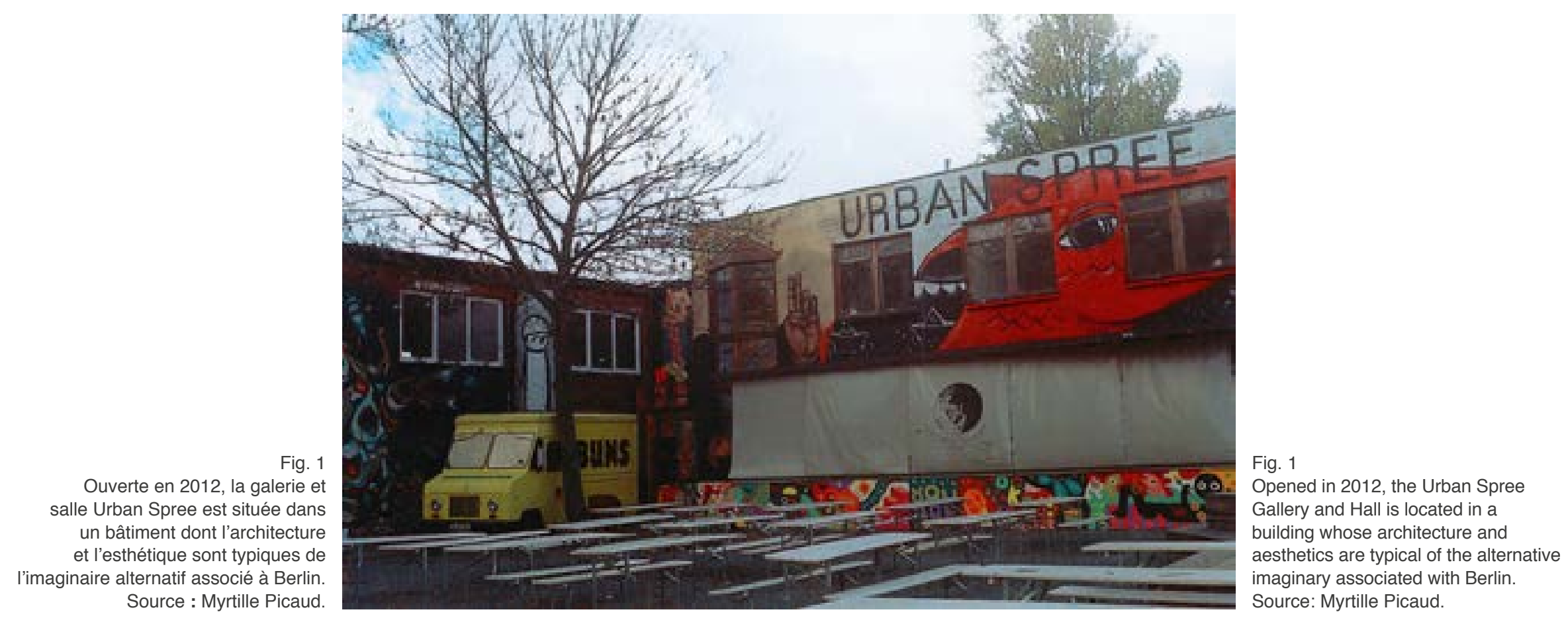


L'économie culturelle des deux villes diverge ainsi, quoique diverses politiques de développement économique par la culture soient mises en œuvre dans la capitale allemande, à l'image du projet contesté Media Spree, qui prévoit l'implantation d'entreprises appartenant aux " industries créatives 》 sur les berges du fleuve éponyme. Si $11 \%$ des entreprises musicales en Allemagne sont désormais implantées à Berlin ${ }^{5}$, Paris concentre quant à elle $29,4 \%$ des salarié.e.s en France exerçant à titre principal dans la culture (INSEE Première 2017). La part la plus importante de l'emploi musical à Berlin réside dans ses institutions musicales classiques (orchestres et salles). Celles-ci sont l'objet d'un soutien public fort : en 2014, le Sénat de Berlin a distribué 40 millions d'euros à divers projets musicaux, auxquels s'ajoutent 135,3 millions à la Fondation des maisons d'opéra de Berlin ${ }^{6}$. Les genres " savants » (classique, opéra, etc.) se taillent la part du lion (près de $99 \%$ si l'on compte la subvention aux opéras). À Paris, les subventions consacrées aux musiques dites actuelles sont supérieures, en montants comme en part du budget total dédié à la musique par la mairie. Celle-ci consacre environ un cinquième des 40 millions d'euros de subventions du Bureau de la musique aux genres « actuels » (chanson, rock, pop, rap, etc.), le restant allant aux musiques « savantes ». Cependant, la prise en compte des subventions du ministère de la Culture et de la Communication renforce drastiquement le poids de ces dernières, puisqu'en $2015 \mathrm{il}$ leur a consacré un peu plus de $90 \%$ des 305 millions alloués à la musique. Ainsi, dans les deux capitales, les musiques classiques sont davantage soutenues par les pouvoirs publics, même si à

Paris le déséquilibre est moins marqué.

5. Senatsverwaltung für Wirtschaft, Energie und Betriebe, Kurzinfo, Musikwirtschaft in Berlin, p. 2, [en ligne] [consulté le 6 novembre 2017].

6. Données accessibles en ligne sur le site du Sénat de Berlin, [en ligne] [consulté le 5 décembre 2016].
Thus, the cultural economies of the two cities are different, although various policies of culture-based economic development have been implemented in the German capital, such as the disputed Media Spree project, which provides for the establishment of businesses belonging to the "creative industries" along the banks of the Spree River. While 11\% of music companies in Germany are currently based in Berlin, ${ }^{5}$ Paris is home to $29.4 \%$ of French culture industry employees (Insee Première, 2017). The majority of music employment in Berlin is within its classical music institutions (orchestras and halls). These receive strong public support: in 2014, the Berlin Senate distributed 40 million euros to various music projects, plus 135.3 million to the Opera House Foundation of Berlin. ${ }^{6}$ The highbrow genres (classical, opera, etc.) receive the lion's share of funding (nearly $99 \%$ if we include the subsidy for operas). In Paris, subsidies for so-called musiques actuelles (a category that broadly speaking is equivalent to that of popular music) are higher, both in total and as a percentage of the total budget earmarked for music by the City Hall. The city's Bureau of Music spends about one-fifth of the 40 million euros on popular genres (French chanson, rock, pop, rap, etc.), with the rest going to highbrow music. However, if we take into account national subsidies from the ministry of culture and communication, the percentage dedicated to the latter drastically increases: in 2015, the ministry spent a little more than $90 \%$ of the 305 million allocated on the highbrow genres. Thus, in both capitals, classical music receives more support from the public authorities, even if the imbalance is less marked in Paris than in Berlin.

5. Senatsverwaltung für Wirtschaft, Energie und Betriebe, Kurzinfo, Musikwirtschaft in Berlin, p. 2. [online] [accessed on 6 November 2017].

6. Data available online on the Berlin Senate website. [online] [accessed on 5 December 2016]. 
Ces éléments permettent de mieux comprendre l'histoire locale et les spécificités des deux sous-champs des salles de musique. On le verra, ils éclairent les conditions sociales de leur autonomie structurelle et la façon dont celle-ci influe sur l'autonomie des programmateur-trice·s, en fonction des spécificités locales de la

division du travail.

\section{Paris : l'autonomie professionnelle de la programmation menacée par la montée des intérêts économiques ?}

Trois critères principaux (Bourdieu 1997 ; Buchholz 2016 : 35) seront retenus afin d'interroger l'autonomie des deux souschamp musicaux : l'existence d'institutions spécifiques au champ ; d'une logique ou d'un principe de vision particulier à cet espace ; de principes de classement et de hiérarchies. L'autonomie structurelle du sous-champ parisien est d'abord examinée, avant de voir comment ses variations influent sur l'autonomie des programmateur.trice.s.

Les luttes en cours dans le champ musical transnational se traduisent de façon relativement visible dans le sous-champ musical parisien, à travers des phénomènes de concentration économique et d'intégration verticale importants, comme dans d'autres grandes villes (Chatterton \& Hollands 2003). Des salles de musique y sont exploitées par des producteurs d'événements nationaux et internationaux, des maisons de disques, voire des multinationales, qui diversifient ainsi leur portefeuille d'activités. L'investissement d'acteurs du champ économique dans le sous-champ des salles de musique se manifeste par des partenariats avec des marques, sous des formes telles que le branding, lorsque des entreprises donnent leur nom à des salles (le Palais omnisports de Paris-
These elements make it possible to better understand the local history and specificities of the two subfields of music venues. As we shall see, they also shed light on the social conditions of structural autonomy within these subfields and the way in which this influences the autonomy of bookers, depending on local specifics in the division of labour.

\section{Paris: Is the Professional Autonomy of Booking Threatened by the Rise of Economic Interests?}

Three main criteria (Bourdieu 2000; Buchholz 2016: 35) will be used to investigate the autonomy of the two music subfields: the existence of institutions specific to the field; a logic or a principle of vision particular to the space; and principles of categorization as well as hierarchies. I will first look at the structural autonomy of the Parisian subfield and then turn to how variations within it affect bookers' autonomy.

The ongoing struggles in the transnational music field are relatively visible in the Parisian music subfield: we can observe significant economic concentration and vertical integration, as in other cities (Chatterton \& Hollands 2003). Music venues are operated by national and international event producers, record companies, and even multinational corporations, which use them to diversify their business portfolios. The investment of economic players in the subfield of music venues can be seen in their partnerships with venues-i.e. "branding," when companies give their name to venues (for example, the Paris-Bercy Palais Omnisports is now called the AccorHotels Arena). It is also evident in the growing presence of companies such as Fimalac and Lagardère, both of 
Bercy se nomme désormais AccorHotels Arena). II est également manifeste dans l'implantation croissante de sociétés telles que Fimalac et Lagardère, toutes deux cotées en bourse, parmi les exploitants de salles parisiennes. Fimalac gère la Salle Pleyel (grande salle aujourd'hui dédiée aux musiques actuelles), participe au capital de sociétés de production de concert et de management (Auguri) et a créé une filiale de production de spectacles et de gestion de salles (3S). Cette société au chiffre d'affaires d'environ 166 millions d'euros a investi dans différents services de billetterie. Lagardère Unlimited Live Entertainment est une filiale spectacle qui organise les tournées d'artistes et de comédies musicales à succès. Elle détient les Folies bergères, le Casino de Paris, $20 \%$ du Zénith et $70 \%$ du Bataclan, des salles aux jauges moyennes, voire importantes, accueillant des musiques actuelles. Les $30 \%$ restants du Bataclan sont partagés par de plus petits opérateurs (Astérios et Alias), qui gèrent aussi plusieurs salles de spectacle (Bouffes du Nord, Flèche d'or, Trois Baudets, etc.), alors que l'Olympia est détenue par Vivendi.

Ces salles donnent quelques exemples d'institutions du souschamp musical rachetées ou exploitées par des agents provenant du champ économique. Certaines de ces salles appartenaient au pôle commercial du sous-champ parisien, quand d'autres fonctionnaient plutôt selon une logique de reconnaissance par les pairs, plus caractéristique du pôle de production restreinte. Ces mutations semblent avoir participé au rapprochement de leurs modes de fonctionnement. Pour les sociétés de management d'artistes et les tourneurs, l'exploitation de plusieurs salles de tailles variables, disséminées géographiquement, facilite la circulation des musicien'ne-s et l'organisation de tournées rentables. Laurent $X$., programmateur dans une salle appartenant à l'une des entreprises précédemment citées, évoque ce phénomène : which are listed on the stock exchange, among the operators of Parisian venues. Fimalac manages the Salle Pleyel (a large hall now dedicated to popular music), makes capital investments in concert production and management companies (Auguri), and has created a subsidiary dedicated to concert production and venue management (3S). This company, with turnover of about 166 million euros, has also invested in various ticketing services. Lagardère Unlimited Live Entertainment is a live events subsidiary that organizes tours of successful artists and musicals. It owns the Folies bergères, the Casino de Paris, 20\% of the Zenith and $70 \%$ of the Bataclan-venues with average to large capacity that host popular music. The remaining $30 \%$ of the Bataclan is owned by a few smaller operators (Astérios and Alias), who also manage several other venues (Bouffes du Nord, Trois Baudets, etc.), while the Olympia is owned by Vivendi.

These venues provide examples of institutions within the music subfield that are owned or operated by agents from the economic field. Some of these venues belong to the commercial pole of the Parisian subfield, while others operate according to a logic of peer recognition, which is more characteristic of the pole of small-scale production. These changes seem to have led to a growing similarity in their modes of operation. For artist management, promoters, and touring companies, operating several venues of varying sizes that are spread out geographically facilitates the circulation of musicians and the organization of profitable tours. Laurent X., a booker at a venue owned by one of the companies mentioned above, mentions this phenomenon: 
Sur la musique actuelle, en France aujourd'hui, [dans la catégorie] gros tourneurs, je crois qu'il n'y en a plus que cinq qui ne sont pas affiliés à un fond de pension, à une multinationale étrangère ou à une maison de disque. [...] Maintenant, quand un artiste Warner sort, il ne va pas aller chez Astérios ou Auguri, chez untel ou untel, il va aller dans les boîtes de spectacle qui sont liées au label. Et du coup, généralement, ces boîtes-là sont aussi propriétaires de salles, donc du coup, le côté un peu repérage [pour le programmateur] « j'aimerais bien faire ci, ça, ça », est un peu biaisé, parce que y'a maintenant des figures imposées, où un artiste rentre dans un tuyau et va faire, va signer en disant : «ça sera ton label, ton tourneur, et tu joueras là ». Donc forcément, le côté indépendant, face à ça, et du coup qui se répercute sur les salles, durcit un peu les choses. (Laurent X., programmateur dans plusieurs salles de concert en France, dont une salle privée moyenne de rock, pop, musiques électroniques, etc., à Paris, âgé d'une quarantaine d'années, formation en école de commerce, parents instituteurs, entretien réalisé à Paris le 9 novembre 2015).

Cette concentration du secteur passe par l'intégration verticale de la filière et la démultiplication des lieux, conduisant à des « figures imposées » qui bouleversent les principes de classement spécifiques au sous-champ parisien des salles de musique. Celui-ci est structuré selon des hiérarchies spécifiques qui segmentent l'offre musicale entre salles différenciées par leurs sélections musicales, leur taille, leur ancienneté (Picaud 2015). Or, la concentration économique et la programmation d'artistes appartenant au catalogue du promoteur qui exploite la salle remettent en question la distribution des artistes selon le capital symbolique accumulé par les lieux. Un principe de vision économique concurrence la logique spécifique du souschamp, marginalisant le travail de programmation dans la sélection des concerts. L'autonomie des programmateurs et programmatrices apparaît ainsi réduite.
In popular music, in France today, [in the category] of big touring agents, I believe there are only five who are not affiliated with a pension fund, a foreign multinational, or a record company [...]. Now, when a Warner artist comes out, he's not going to go to Asterios or Auguri, or to so-and-so, he'll go to the promoters that are connected to the label. And these companies also own venues, so the aspect of looking for new acts, [the booker saying] "I would like to do such and such," is a little biased, because now there are predetermined paths, where an artist enters the circuit and when they sign, it's: "this will be your label, this will be your booker, and you will play these venues." So, inevitably, faced with that-and it also affects venues - the independent side, that becomes a bit harder. (Laurent $\mathrm{X}$., booker in several concert venues in France, including a mid-sized private rock, pop, electronic music, etc. venue in Paris, around 40 years old, business school training, parents are teachers, interview conducted in Paris on 09 September 2015).

This concentration of the sector occurs through vertical integration and multiple ownership of venues, leading to "predetermined paths" that upset the traditional classificatory principles specific to the Parisian subfield of music venues. The latter is structured according to specific hierarchies that allocate acts to venues that are differentiated in terms of music selection, size, and age (Picaud 2015). Economic concentration and the practice of booking artists from the catalogue of the promoter who operates the venue call into question this distribution of artists according to venues' symbolic capital. An economic principle competes with the specific logic of the subfield, marginalizing the task of booking in the selection of artists. Thus, the autonomy of bookers appears reduced. 
Dans de rares cas, généralement des salles symboliquement dominantes et reconnues de longue date, pour lesquelles le rachat ou changement d'exploitant demeure récent, les programmateurs et programmatrices parviennent néanmoins à maintenir une plus grande autonomie professionnelle. II s'agit souvent d'intermédiaires appartenant à la scène parisienne depuis de nombreuses années, la plupart ayant acquis de solides réputations adossées à leur centralité dans des réseaux professionnels clefs dans le contrôle de l'accès à la programmation (Dutheil-Pessin \& Ribac 2017). Profitant malgré tout de l'intégration verticale dans laquelle s'inscrit leur activité, ils peuvent programmer des artistes dont les cachets ont explosé au cours des années 2010. La concurrence qu'ils livrent aux acteurs dominants du marché mène néanmoins certains d'entre eux à se concentrer sur une offre musicale particulière en termes d'artistes et de styles ${ }^{7}$, reconnue mais aussi rentable, qui participe à l'homogénéisation locale des programmations, en lien avec les hiérarchies du champ musical transnational. En témoigne la concentration des programmations sur certains genres (rock musiques électroniques, pop) et sur des artistes renommé.e.s, souvent des États-Unis, du Royaume-Uni ou d'Europe du Nord et d'Allemagne. C'est ainsi par la convergence de critères musicaux et économiques d'appréciation de la valeur musicale que se traduit l'hétéronomie structurelle accrue du sous-champ parisien des salles de musique.

7. Si l'observation des programmations parisiennes témoigne de la récurrence de certains artistes ou styles, selon Timothy Dowd, la concentration économique du marché musical ne conduit pas forcément à une baisse de la diversité musicale (part de nouveaux artistes) si l'organisation de la production est décentralisée (2004). La transposition de son analyse à la musique live est cependant complexifiée par la diversité des genres musicaux, des formats d'organisation de concert et l'échelle géographique restreinte, dans laquelle le bassin des publics n'est pas infiniment extensible.
In rare cases-usually symbolically dominant and long-recognized venues that have only recently been purchased or changed operators-bookers manage to maintain greater professional autonomy. These are often intermediaries who have been part of the Parisian scene for many years, and most have acquired a strong reputation backed by their centrality in the professional networks in which they are key to controlling access to booking (Dutheil-Pessin \& Ribac 2017). Profiting, in spite of everything, from the vertical integration that has come to dominate their profession, they are able to schedule artists whose fees have skyrocketed over the course of the 2010s. However, being in competition with the dominant market players leads some of them to focus on particular artists or music styles ${ }^{7}$ that are both recognized and profitable, thus contributing to the local homogenization of programming, in connection with the hierarchies of the transnational music field. This can be seen in the concentration of gigs of certain genres (rock, electronic music, pop) and on famous artists, often from the United States, the United Kingdom, or northern Europe and Germany. Thus, the increased structural heteronomy of the Parisian subfield of music venues is reflected in the convergence of music and economic criteria in assessing music value.

7. While music selection in Parisian venues is marked by the recurrence of certain artists or styles, according to Timothy Dowd, economic concentration of the music market does not necessarily lead to a decline in music diversity (expressed in terms of the proportion of new artists) if the organization of production is decentralized (2004). The transposition of his analysis to live music is, however, made more complex by the diversity of music genres, concert organization formats, and the restricted geographical scale, in which the audience pool is not infinitely extensible. 
Peut-on « pour autant dire que la pression des valeurs du marché contribue à la dilution de l'autonomie et de l'expertise professionnelles ou faut-il voir plutôt une transformation de cellesci dès lors que le groupe est soumis à des forces exogènes ? " (Boussard, Demazière, Milburn 2010 : 65) Les programmateurs définissent leur activité par le monopole de la sélection et par le contrôle de l'ajustement entre artiste et lieu de concert. Leur travail ne se limite pas à celui de gatekeepers (Shoemaker \& Vos 2009), portiers acceptant ou refusant des flux qui leur arrivent ; ils jouent également un rôle dans la production de la musique et dans la définition de ses publics. À ce titre, l'autonomie des programmateurs et programmatrices semble menacée par la concentration économique et l'intégration verticale.

En effet, dans les salles exploitées par des tourneurs ou producteurs de spectacles, la programmation peut être décidée par d'autres intermédiaires qui officient en amont des programmateurs de salle. La perte du monopole sur l'activité de programmation, par la division du travail, tout comme l'accroissement du contrôle managérial (Champy 2009) dont témoignent ces critères de sélection des artistes, sont susceptibles de réduire leur autonomie professionnelle. Ainsi, certains lieux se tournent vers la location de la salle à des producteurs extérieurs (Guibert \& Sagot-Duvauroux 2014). La programmation tend alors à se réduire à la recherche d'opérateurs disposés à louer la salle, à l'organisation des dates, etc. Ce cas de figure rappelle que l'institutionnalisation du travail de programmation viale développement professionnel du groupe des programmateurs et programmatrices ne va pas de soi. Elle peut effectivement être concurrencée par le développement de systèmes organisationnels de grande ampleur, Andrew Abbott suggérant que le travail d'expertise est alors accompli par des chaînes de non-professionnels (1988 : 324-326). Dans les salles exploitées par des multinationales, ces non-professionnels de la musique sont généralement nommés responsables marketing
Can we "therefore say that the pressure of market values contributes to diluting autonomy and professional expertise, or are these rather transformed when the group is subjected to exogenous forces?" (Boussard, Demazière, Milburn 2010: 65). Bookers define their work in terms of a monopoly on selection as well as control over the connection between artists and concert venues. Their work is not limited to that of gatekeepers (Shoemaker \& Vos 2009), who are charged with allowing in or refusing what comes their way; they also play a role in producing music and defining its audience. In this respect, the autonomy of bookers seems threatened by economic concentration and vertical integration.

Indeed, in venues operated by touring companies or event producers, artist selection can be decided by other intermediaries who work upstream of bookers. Bookers' loss of monopoly over programming due to this division of labour as well as to increased managerial control (Champy 2009), evidenced by these selection criteria for artists, is likely to reduce their professional autonomy. Thus, some venues turn to renting their space to outside producers (Guibert \& Sagot-Duvauroux 2014). In-house booking then tends to be reduced to looking for operators willing to rent the venue, organizing dates, etc. Such cases remind us that the institutionalization of programming work through the professional development of bookers is not straightforward. This form of institutionalization may in fact be in competition with the development of large-scale organizational systems; Andrew Abbott suggests that in such cases, specialist work is done by chains of non-professionals (1988: 324-326). In venues run by multinationals, these non-music professionals are usually called marketing or sales managers rather than bookers-a sign that they belong to another professional group. As in sectors where subcontracting is 
ou commerciaux, et non plus programmateurs, témoignant de leur appartenance à un autre groupe professionnel. De façon similaire aux secteurs liés à la sous-traitance, des prescriptions en cascade entre organisations (managers, tourneurs, producteurs locaux d'événements, directeurs commerciaux) mènent à une forme d'« autonomie contrôlée » (Appay 2005) des directeurs commerciaux de salles. Le système des locations reposant sur la rentabilité des événements, ces intermédiaires sont aussi situés au pôle le moins autonome du sous-champ des salles de musique, où l'évaluation de

la valeur musicale s'adosse à la demande externe.

L'autonomie du sous-champ parisien est ainsi réduite, ce qui se traduit par la transformation des critères d'évaluation de la musique et résulte en la présence accrue de certains styles et artistes rentables dans les salles étudiées. L'autonomie professionnelle des programmateurs semble menacée par ces phénomènes, la montée des intérêts économiques conduisant également certains d'entre eux à redéfinir leur travail et leur territoire professionnel. Cette redéfinition se fait par l'adjonction de compétences de gestionnaire ou d'autres segments du système d'intermédiation, comme la promotion de concerts ou l'organisation de tournées. Jean M. affirme ainsi que :

[programmateur] y'a pas de légitimité à ce que ça soit un métier à part entière de mon point de vue. [...] le directeur artistique qui ne fait que programmer, pour moi c'est fini, ça n'a pas d'avenir, car on ne peut pas couper l'activité de programmation de l'activité de gestion. Parce qu'aujourd'hu il faut créer ses propres ressources avec l'activité de programmation. (Jean M., programmateur, salle parisienne privée de taille moyenne de musiques classiques, 50 ans, master en musicologie et lettres, père cadre dans une grande entreprise automobile, mère au foyer, entretien réalisé à Paris le 10 septembre 2014) common, cascading directives between organizations (managers, bookers, local event producers, and sales managers) lead to a form of "controlled autonomy" (Appay 2005) on the part of venue sales managers. Since the rental system is based on the profitability of events, these intermediaries also belong to the least autonomous pole of the music venue subfield, where evaluation of music value is based on external demand rather than artistic criteria.

The autonomy of the Parisian subfield is thus reduced, resulting in a transformation of the criteria by which music is evaluated and the increased presence of certain profitable styles and artists in the venues studied. The professional autonomy of bookers seems threatened by these phenomena, and the rise of economic interests is leading some of them to redefine their work and professional territory. Such redefinition may include adding management skills or participating in other segments of the intermediation system, such as concert promotion or tour organization. Jean M. asserts that

from my point of view, there is no legitimacy in [in-house booking] being a fully-fledged profession [...] the artistic director who only does programming, for me that's over, there is no future there, since you can't separate booking from management. Because today you have to create your own resources with programming. (Jean M., booker, Parisian privately-owned average-sized classical music venue, 50 years old, masters in musicology and literature, father was an executive in a large car company, mother was a homemaker; interview conducted in Paris on 10 September 2014). 
Le poids des critères économiques dans les principes de vision et de division du sous-champ parisien est renforcé, son hétéronomisation passant aussi par l'adaptation subjective de programmateurs qui monopolisent des activités gestionnaires.

Certains programmateurs et programmatrices parviennent à réintroduire du jeu dans la sélection musicale en contournant les logiques économiques. Une programmatrice de musiques électroniques dans un grand club privé noue ainsi des liens directs et personnels avec les programmateurs d'un club berlinois renommé, à qui elle rend régulièrement visite. En court-circuitant d'autres intermédiaires, elle espère obtenir l'exclusivité parisienne de leurs artistes, avant que ses concurrents ne sortent " leur carnet de chèque » avec lequel elle ne peut rivaliser. Un programmateur a créé sa propre agence d'entrepreneur de spectacles et organise un

festival,

avec des prises de risque dans des choix, et des partis pris dans les esthétiques des artistes qu'on défend. On n'ira jamais sur un projet d'un artiste par lequel on n'est pas $100 \%$ convaincu artistiquement quoi, pour aller vite. (Édouard T., salle subventionnée de taille moyenne présentant des esthétiques diverses, pop, rock, électroniques, rap, chanson, programmateur âgé d'une quarantaine d'années, père dentiste, mère au foyer, diplômé en sciences sociales à l'université et d'une école privée en gestion de la culture, entretien réalisé à Paris le 29 octobre 2015).

Ce type d'intégration verticale de la filière à petite échelle est destiné à concurrencer celle qui a lieu dans de plus grosses salles. Les pouvoirs publics, en particulier la mairie de Paris, subventionnent ponctuellement ces entreprises ou soutiennent des lieux destinés à un genre (La Place, Trois Baudets, dédiées respectivement au
The influence of economic criteria on the principles of vision and division of the Parisian subfield is reinforced, and its heteronomization also occurs through the subjective adaptation of bookers who monopolize managerial activities.

Some bookers manage to reintroduce some leeway in music selection by circumventing economic logic. Thus, one electronic music booker at a large private club establishes direct and personal links with the bookers of a well-known Berlin club, whom she regularly visits. By bypassing other intermediaries, she hopes to get the exclusive right to book their artists in Paris, before her competitors can "flash their cheque book," with which she cannot compete. Another booker has created his own event promotion company and organizes a festival,

where we take risks in the choices we make, and support the aesthetics of the artists we support. In short, we will never go ahead on a project by an artist who we are not a hundred per cent convinced of artistically. (Édouard T., medium-sized subsidized venue with various aesthetics including pop, rock, electronic, rap, chanson; booker in his forties; father a dentist, mother a homemaker; one degree in social science from a university and another in cultural management from a private school; interview conducted in Paris on 29 October 2015).

This type of small-scale vertical integration is intended to compete with the vertical integration that occurs in larger venues. The public authorities, in particular the Paris City Hall, occasionally subsidize these companies or fund venues dedicated to a certain genre (for example, La Place and Trois Baudets, which are dedicated to hip 
hip hop et à la chanson francophone). Cependant, l'action des pouvoirs publics demeure ponctuelle. Si elle garantit davantage d'autonomie professionnelle pour les intermédiaires dont les salles sont subventionnées, elle peine à renforcer l'autonomie structurelle du sous-champ musical parisien. hop and French chanson respectively). However, such actions by the public authorities remain occasional. While such funding guarantees more professional autonomy for the intermediaries whose venues are subsidized, it fails to strengthen the structural autonomy of the Parisian music subfield.

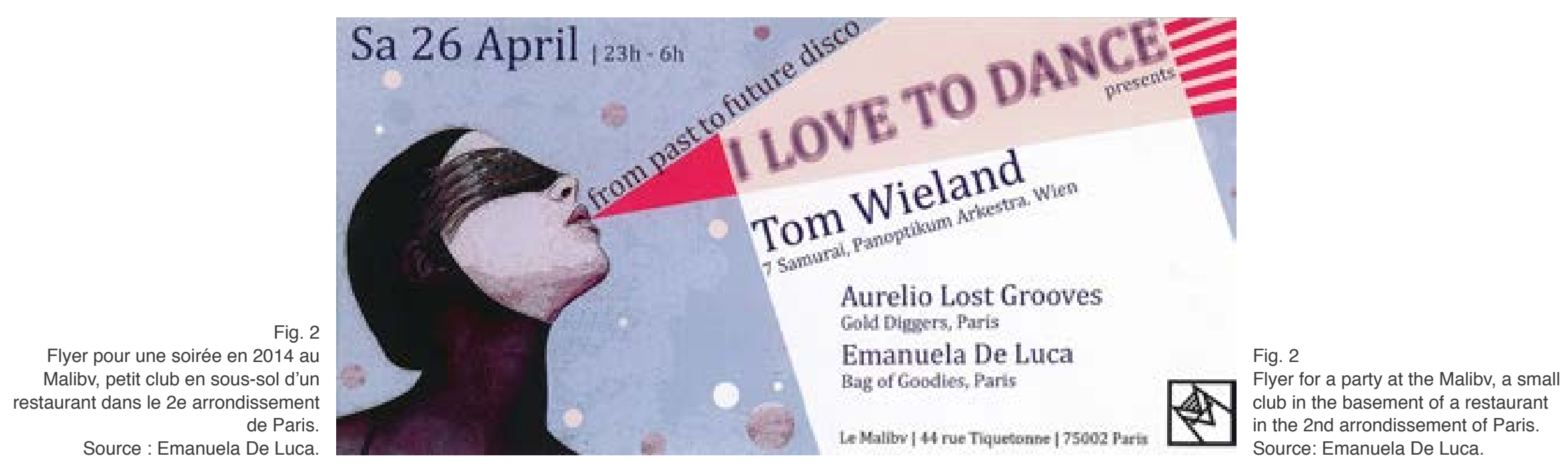

\section{Berlin : une autonomie structurelle favorisée par la faiblesse de l'économie musicale locale ?}

À Berlin se sont installés différents grands groupes, comme Universal Music, depuis le début des années 2000. Leur présence est attestée par la construction en cours de la Mercedes Benz Platz, qui accueille l'aréna homonyme, appartenant à la multinationale Anschutz Entertainment Group, et une seconde salle détenue par une grande compagnie d'assurances. Par ailleurs, la multinationale CTS Eventim exploite la Waldbühne, une aréna en plein air de

\section{Berlin: Is the Structural Autonomy Bolstered by the Weakness of the Local Music Economy?}

Various major groups such as Universal Music began establishing themselves in Berlin in the early 2000s. Their presence is evidenced by the ongoing construction of the Mercedes Benz Platz, which hosts an arena of the same name that is owned by the multinational Anschutz Entertainment Group as well as a second venue belonging to a major insurance company. In addition, the multinational CTS Eventim operates the Waldbühne, a 50,000-seat 
50000 places. Elle a aussi tenté d'acquérir le promoteur de spectacles Four Artists basé à Berlin mais cette opération a été bloquée en 2017 par l'autorité allemande de la concurrence. Malgré ces exemples et une forte concentration dans le marché musical allemand, le moindre développement économique local semble avoir freiné la concentration à Berlin. Comme dans le marché immobilier, la situation change progressivement, notamment sous l'impulsion des politiques publiques qui tentent de dynamiser l'économie en s'appuyant sur les secteurs culturels et informatiques (Colomb 2012). Des petites salles sont exploitées par une même entreprise, telles que le Lido, Astra et Bi Nuu ou encore Festsaal, Paloma et Monarch dont le gérant est le même. Néanmoins, ces entreprises sont moins profitables et ont moins d'emprise nationale que leurs homologues parisiennes. Leur pérennité est menacée par le niveau de vie relativement bas comparé à d'autres grandes villes, alors que les cachets des artistes circulant au niveau international connaissent eux une croissance importante. D'autre part, plusieurs programmateur.trice.s salarié.e.s évoquent la concurrence d'autres salles, dont la jauge est parfois importante, qui diffusent des styles musicaux similaires mais dont les coûts sont réduits par un fonctionnement bénévole ou non déclaré et

l'absence de mise aux normes.

Ces salles au fonctionnement « alternatif » sont relativement diverses. Certaines ont une durée de vie très courte et leur programmation comprend principalement des artistes résidant à Berlin, faiblement rémunéré·e·s. D'autres sont plus anciennes (début des années 1990) et détiennent un important capital symbolique du fait de leur histoire et de leurs programmations. Les salles associatives, plus nombreuses à Berlin, fonctionnent souvent selon ce modèle. Certaines sont homologues aux salles parisiennes moyennes et renommées, qui ne comprennent, elles, pas de bénévoles. Ces salles berlinoises sont nombreuses à véhiculer un principe de vision particulier qui structure outdoor arena. CTS Eventim also tried to acquire the Berlin-based event promoter Four Artists, but the acquisition was blocked in 2017 by the German competition authority. Despite these examples and the strong concentration of the German music market, a lower level of economic development seems to have hindered concentration in Berlin. As in the real estate sector, this situation is gradually changing, due in particular to public policies seeking to boost the economy on the basis of the cultural and IT sectors (Colomb 2012). Small venues may be operated by a single company; for example, Lido, Astra, and Bi Nuu share the same management, as do Festsaal, Paloma, and Monarch. Nevertheless, these companies are less profitable and have less national influence than their Parisian counterparts. Their longevity is threatened by Berlin's relatively low standard of living compared with other major cities, as well as the fact that the fees paid to artists who tour internationally are growing significantly. In addition, some salaried bookers mention competition from other, sometimes rather large venues, which play similar music styles but have lower costs because they are run by volunteers or operate under the table, and whose buildings do not comply to legal standards.

These "alternative" venues are relatively diverse. Some have a very short lifespan and their gigs mainly include artists who live in Berlin and are paid little. Others are older (dating from the early 1990s) and have significant symbolic capital because of their history and music selections. Non-profit venues, which are more numerous in Berlin, often fit this model. Some are counterparts to medium-sized, well-known Parisian venues that do not employ volunteers. Many of these Berlin venues convey a particular vision, which structures the hierarchies specific to the Berlin subfield. They profess an ideology of economic disinterestedness, which gives precedence 
les hiérarchies propres au sous-champ berlinois. Elles professent une idéologie du désintéressement qui fait primer le refus de tout profit économique. Celle-ci est liée à une conception vocationnelle de l'activité artistique, mais aussi à l'histoire de la "renaissance » du sous-champ musical berlinois après la chute du Mur ${ }^{8}$. Le capital symbolique de certains membres rend leur discours très audible, même s'ils sont minoritaires. II se traduit notamment par le refus de rentabiliser l'organisation de concerts, voire parfois de percevoir une rémunération. Les propos d'Anna R. ou de Konstantin K. sont représentatifs de ce positionnement :

Officiellement tu vois, il y a de l'argent qui rentre et qui sort, pour payer le loyer, il y a un compte séparé et ce type de chose, mais c'est vraiment non commercial, on ne se distribue jamais d'argent, on ne se rémunère pas. Parce que la règle la plus importante ici est que personne qui s'implique ne gagne d'argent, comme ça tu gardes l'esprit libre pour faire les choses qui sont importantes et tu t'investis pour... Parce que si tu commences à te payer, ensuite tu deviens corrompu. Tu te dis "Ok, je vais faire une soirée supplémentaire, juste pour gagner quelques centaines d'euros. " (Anna R., programmatrice dans une petite salle associative à Kreuzberg qui présente des musiques expérimentales, bookeuse dans une agence indépendante, 30 ans, master de management culturel, père ingénieur, mère acheteuse anonyme, entretien réalisé à Berlin le 16 octobre 2013).

8. L'ouverture de nombreuses salles au cours des années 1990 se fait dans des lieux vacants dont la propriété est incertaine. De nombreux bars illégaux sont créés par des collectifs composés de militant·e·s de groupes d'extrême gauche, qui importent des pratiques et valeurs du champ politique. Cette période reste centrale dans la structure du sous-champ berlinois aujourd'hui (Picaud 2017). to the refusal of any economic profit. This is linked to a vocational conception of artistic activity, as well as to the history of the "rebirth" of Berlin's music subfield after the fall of the wall. ${ }^{8}$ The symbolic capital of some members makes their discourse very present, even if they are in the minority. It is reflected in particular by a refusal to make the organization of concerts profitable, and even sometimes a refusal to be compensated. The words of Anna R. and Konstantin $\mathrm{K}$. are representative of this discourse:

There is like, you know, officially, money coming in and out, paying the rent and a separate account and this sort of stuff, but it's like totally non-profit, we never distribute any kind of money to ourselves or pay ourselves. Because the biggest rule here is that nobody who is involved here earns money, so you keep your mind free to really do the things that are important, and you really put your heart to [...] because if you start to pay yourselves out, then you become corrupt. You say, "Ok I take on another party just so I can earn a few hundred euros." (Anna R., booker at a small nonprofit venue in Kreuzberg that presents experimental music, promoter at an independent agency; 30 years old; masters in cultural management; father engineer; mother anonymous buyer; interview conducted in Berlin on 16 October 2013).

8. In the 1990s, many venues opened in vacant sites whose ownership was unclear. Many illegal bars were created by collectives of activists from farleft groups, who imported practices and values from the political field. This period remains central to the structure of the Berlin subfield today (Picaud 2017). 
On a toujours cru, enfin même si c'est contesté dans le groupe je dois dire, mais en règle générale, la plupart des gens dans le groupe disent ou pensent que c'est mieux d'être bénévoles, et de travailler les uns avec les autres dans un esprit bénévole, plutôt que dans un environnement plus entrepreneurial, où les gens sont payés et où il y a un bénéfice à faire. (Konstantin K., 45 ans, programmateur dans une salle expérimentale et associative à Prenzlauer Berg de très petite jauge, effectue des missions rémunérées dans l'informatique, diplôme Abitur [équivalent au baccalauréat], père docteur en physique et dramaturge, mère psychiatre, entretien réalisé à Berlin le 18 novembre 2013).

Ainsi, puisque la salle n'a pas d'impératif de rentabilité, le critère d'évaluation artistique ne seraitjamais inféodé au critère économique, ni à celui de la demande extérieure. Les programmations par des collectifs et l'exercice d'une autre activité rémunérée en parallèle permettent cette dénégation de l'intérêt économique. Les recettes générées paient le loyer et les artistes sont nombreux à s'y produire malgré de faibles cachets, ces lieux disposant d'un important capital symbolique à Berlin. Toutefois, cette situation a pour corollaire une faible autonomie professionnelle des programmateurs. Ils ont peu de marge de manœuvre quant à leurs ressources et la définition de leur activité qui repose sur la mobilisation de collectifs. Le renouvellement régulier des membres des collectifs, lié aussi à la difficulté d'en vivre, ne permet pas la structuration d'un réseau d'intermédiaires fort. Ainsi, le plus faible développement professionnel de la gestion de salles limite aussi la diffusion de critères dominants d'évaluation de la valeur musicale, qui permettraient la rationalisation économique de la programmation.
We always thought, or even though that is contested in the group, I must say, but in general, as a general rule, most of the people in the group, say or think, that it's better to be volunteers and to like, work in a volunteer spirit with each other than sort of like, in a more corporate environment, where people get paid, and there's a profit to be made. (Konstantin K., 45, booker at a very small, experimental, nonprofit venue in Prenzlauer Berg, performs paid assignments in computer science; Abitur degree; father physicist and playwright, mother psychiatrist; interview conducted in Berlin on 18 November 2013).

According to these bookers, since there is no requirement that the venue be profitable, the criterion of artistic evaluation is never subordinated to the economic criterion, or to that of external demand. The fact that booking is done by collectives whose members have a parallel paid activity allows for this repudiation of economic interest. The revenues generated pay the rent, and many artists perform there despite being paid little, since these venues have significant symbolic capital in Berlin. However, the corollary to this situation is low professional autonomy on the part of bookers. They have little room for manoeuvre with respect to their resources and the definition of their activity, which depends on the mobilization of collectives. Frequent turnover of collective members, which is also linked to the difficulty of making a living from this work, does not allow for a strong network of intermediaries. Weaker professional development in venue management also limits the diffusion of dominant criteria for assessing music value, which would allow for the economic rationalization of booking. 
Les conditions de possibilité de cette autonomie structurelle s'appuient sur les faibles contraintes économiques auxquelles sont soumises ces salles, en particulier en ce qui concerne le prix de l'immobilier. Les rares subventions publiques allant à la freie Szene (scène indépendante) permettent également à celles dont la sélection musicale est reconnue de survivre sur le moyen terme. Aux montants très limités, ces aides ne participent que peu à l'institutionnalisation de la scène indépendante, hors musiques classiques. Les trajectoires de ces intermédiaires, à l'image de Konstantin K., sont aussi l'une des conditions de possibilité de cette autonomie structurelle. Âgé de 45 ans, ce programmateur a vécu dans un squat à Prenzlauer Berg après la chute du Mur. II s'y est formé à l'organisation d'événements ainsi qu'à l'écoute de musiques expérimentales, notamment dans la Echtzeitszene (scène freejazz berlinoise), ce qui influe sur sa vision de ce que doit être une salle de musique. Les individus entrant dans le champ à la fin des années 2000, même investis dans des lieux alternatifs, ont des aspirations légèrement différentes des siennes. Certains promeuvent un désintéressement comme garantie d'autonomie de la musique qui renvoie aussi à leurs difficultés d'insertion dans l'emploi musical. Cherchant à professionnaliser l'activité de programmation, ils contestent le principe de nonrémunération et les pratiques qui lui sont associées, luttant pour une autonomie professionnelle de la programmation plus importante. Pourtant, la faiblesse de l'économie musicale locale rend difficiles les carrières d'intermédiaires, les positions désintéressées permettant alors de faire de nécessité vertu.

En outre, ces lieux, fonctionnant sur un modèle collectif (un tiers de ceux enquêtés), ne sont pas seuls à porter une logique qui fait primer les critères artistiques sur les critères économiques. Elle est aussi mise en avant par des salles à la fois renommées et économiquement rentables, même si elle ne se traduit pas par le refus de se rémunérer soi-même. Florian F., programmateur dans un grand club privé renommé de Berlin-Est, affirme ainsi : «ce
The conditions of possibility of this structural autonomy are based on the weak economic constraints to which these venues are subjected, in particular with regard to the price of real estate. The few public subsidies that go to the freie Szene (independent scene) also allow venues whose music selection is recognized to survive in the medium term. These subsidies, which are very limited in amount, contribute little to the institutionalization of the independent scene, outside of classical music. The trajectories of intermediaries such as Konstantin K. are also part of the conditions of possibility of this structural autonomy. Aged 45, this booker lived in a squat in Prenzlauer Berg after the fall of the Wall. There, he was introduced to event organization and became familiar with experimental music, especially Berlin's free jazz scene (Echtzeitszene), which continues to influence his vision of what a music venue should be. Individuals who entered the field in the late 2000s, even in alternative venues, have slightly different aspirations. Some promote disinterestedness as a guarantee of the music's autonomy; this also corresponds to their difficulties finding music employment. Seeking to professionalize booking, they contest the principle of non-remuneration and the practices associated with it, fighting for greater professional autonomy. However, the weakness of the local music economy makes the careers of intermediaries difficult, and adopting the disinterested position allows them to make a virtue of necessity.

In addition, these venues, operating on a collective model (one third of those surveyed), are not the only ones to base themselves on a logic that puts artistic before economic criteria. Such logic is also foregrounded by venues that are both renowned and economically profitable, even if it does not translate into a refusal to be remunerated. Florian F., booker at a well-known club in East Berlin, says: What we do I think it's not really, it's kind of anti-music 
qu'on fait je pense que ce n'est pas vraiment, enfin c'est l'inverse d'un business musical » (45 ans, parents ouvriers, master de music management, entretien réalisé à Berlin le 13 novembre 2013). Cette logique se matérialise dans des institutions comme la Berlin Club Commission, qui regroupe environ 200 membres dont elle promeut les intérêts dans différents cadres. Si elle souligne le rôle de développement économique des activités musicales, cette commission défend une vision relativement étroite des "clubs ", non pas en fonction des genres programmés, mais de l'aspect non commercial de l'activité. Revendiqué par ces institutions, comme par différentes catégories de lieux, ce principe de vision structure les hiérarchies du sous-champ musical

Lefaibledéveloppementprofessionneldel'activité de programmation a freiné la généralisation de critères économiques, contribuant ainsi à l'autonomie structurelle du sous-champ berlinois. II a aussi limité l'autonomie professionnelle d'une large part des programmateurs. Néanmoins, une partie de ceux travaillant dans les clubs renommés de musiques électroniques parvient à stabiliser son activité, en regroupant la programmation avec la gestion de labels et d'artistes " résident·e.s ». Certains d'entre eux, comme le directeur du club emblématique le Tresor, ont ainsi participé à l'exposition transnationale de Berlin, par la création de réseaux musicaux entre villes et la diffusion d'artistes devenu.e.s ensuite des vedettes Leurs artistes sont recherché·e.s par les programmateur.trice.s à l'étranger et les DJs souhaitent jouer dans leurs clubs, aux portes desquels se pressent les publics. Ces salles sont dotées d'un fort capital symbolique, que leurs mobilisations collectives pour faire valoir le « son alternatif de Berlin » à l'international contribuent à renforcer. La situation est semblable dans certaines salles de musiques classiques, dont le capital symbolique est reconvertible au niveau global. Le programmateur de l'une des plus grandes salles de concert berlinoises explique ainsi que certains orchestres business. (45 years old; working-class parents; masters in music management; interview conducted in Berlin on 13 November 2013). This logic is embodied in institutions such as the Berlin Club Commission, which has around 200 members whose interests it promotes in different settings. While emphasizing the economic development of music activities, this commission defends a relatively exclusive view of "clubs" - not in terms of genre, but rather the non-commercial aspect of their activity. This vision structures the hierarchies of the music subfield and is proclaimed by these institutions as well as by different categories of venue.

Weak professional development of booking has slowed down the generalization of economic criteria, thus contributing to the structural autonomy of the Berlin subfield. It has also limited the professional autonomy of a large percentage of bookers. Nevertheless, some of those working in well-known electronic music clubs have managed to stabilize their activity, by combining booking with managing labels and having "resident" artists. Some of them, such as the director of the iconic club Tresor, have participated in Berlin's transnational exposure, creating music networks between cities and circulating artists who then become star performers. Their artists are sought after by bookers abroad and DJs want to play in their clubs, which the public flocks to. These venues are endowed with strong symbolic capital, which their collective efforts to highlight the "Berlin alternative sound" at the international level reinforce. The situation is similar in some classical music halls, whose symbolic capital is internationally re-convertible. The booker of one of the largest concert halls in Berlin explains that some foreign orchestras, with which connections have existed for decades, lower their fees in order to perform there. This allows him to maintain high quality programming that his budget would 
étrangers, avec lesquels des liens existent depuis parfois des décennies, réduisent leurs cachets pour s'y produire. Cela lui permet de maintenir une programmation de grande qualité que son budget n'aurait initialement pas autorisé. Ainsi, comme à Paris, la monopolisation par certains programmateurs de plusieurs segments du système d'intermédiation permet de contourner les contraintes économiques imposées par le marché international de la musique live. Le lien entre autonomie structurelle et autonomie professionnelle de ce groupe spécifique de programmateurs repose ainsi sur la position dominante de Berlin, en musiques classiques et électroniques, dans le champ musical transnational.

\section{Conclusion}

Ainsi, autonomie professionnelle des programmateurs et programmatrices et autonomie structurelle du champ des salles de musique ne se renforcent pas nécessairement l'une et l'autre. Le contexte historique de formation du sous-champ, les conditions économiques locales, les configurations professionnelles, sont autant de conditions de possibilité de leur articulation. À Paris, le développement professionnel a facilité la concentration économique au sein du sous-champ musical. L'investissement d'acteurs du champ économique transforme sa logique propre, en renforçant le poids des critères économiques dans la sélection et en bousculant ainsi ses hiérarchies. Si cette perte relative d'autonomie structurelle menace à terme l'existence des programmateurs, les plus dominant·e.s d'entre eux préservent temporairement leur autonomie professionnelle grâce à un capital symbolique que captent les entreprises exploitant leurs salles. Malgré cela, la redéfinition de leur travail, par l'adjonction d'activités managériales ou celles d'autres intermédiaires, témoigne de la montée des

intérêts économiques. not otherwise allow for. Thus, as in Paris, the monopolization by some bookers of several segments of the intermediation system makes it possible to circumvent the economic constraints imposed by the international live music market. The link between structural autonomy and the professional autonomy of this specific group of bookers thus rests on Berlin's dominant position in classical and electronic music in the transnational music field.

\section{Conclusion}

We have seen that the professional autonomy of bookers and the structural autonomy of the field of music venues do not necessarily reinforce each other. The historical context of the formation of the subfield, local economic conditions, and professional configurations all affect how they are connected. In Paris, professional development has facilitated economic concentration within the music subfield. The investment of actors from the economic field transforms its logic, reinforcing the weight of economic criteria in selection, and thereby upsetting its hierarchies. While this relative loss of structural autonomy ultimately threatens the long-term existence of bookers, the most dominant of them temporarily preserve their professional autonomy thanks to the symbolic capital that the companies operating their venues can harness. In spite of this, the redefinition of their work through the addition of managerial activities or other intermediary work testifies to the rise of economic interests. 
À Berlin, le plus faible développement professionnel de la programmation, le moindre coût de la vie et l'économie culturelle peu développée freinent l'arrivée des acteurs du champ économique. Le refus de subordonner les critères d'évaluation musicaux à la rentabilité économique, revendiqué par différents groupes de programmateurs, renforce l'autonomie structurelle du sous-champ des salles de musique. Toutefois, la survie d'une partie des salles est suspendue à l'investissement désintéressé d'individus gagnant leur vie autrement qu'en programmant, ce que contestent de façon croissante les plus jeunes intermédiaires, qui tentent d'accroître leur autonomie professionnelle. Ce fonctionnement désintéressé a pour l'instant été entretenu par l'arrivée d'individus attirés par l'aura internationale de la ville, continuant de pallier la grande faiblesse des subventions publiques. Dans ce contexte, celui d'un groupe professionnel fragmenté, la plus faible autonomie professionnelle semble bien être l'une des conditions de possibilité de l'autonomie structurelle du sous-champ berlinois des salles de musique. La condition pour lier autonomie structurelle et autonomie professionnelle, ce qui est le cas d'une minorité de programmateurs, repose sur la position dominante dans le champ musical transnational pour certains genres, comme les musiques électroniques.

Dans les deux capitales, les programmateurs tentant de regagner leur autonomie professionnelle sans pour autant concourir davantage à la montée des intérêts économiques recourent à l'adjonction de territoires professionnels relevant de la circulation internationale d'artistes. Ainsi, l'analyse des formes de l'autonomie professionnelle en fonction de l'autonomie structurelle d'un (sous-) champ semble devoir inclure l'« autonomie verticale » par rapport au champ transnational. C'est particulièrement le cas pour un objet très internationalisé tel que la musique. L'autonomie structurelle des champs de la musique vivante de Paris et Berlin est ainsi liée à l'interpénétration entre champs musical et économique globaux. La
In Berlin, the weaker professional development of booking, a lower cost of living, and a less developed cultural economy hamper the intervention of economic actors. The refusal to subordinate criteria of music evaluation to economic profitability, proclaimed by various groups of bookers, reinforces the structural autonomy of the music venue subfield. However, the survival of some of the venues depends on volunteer investment by individuals who make their living from other activities-something that is increasingly being challenged by the youngest intermediaries, who are trying to increase their professional autonomy. For now, this non-profit based form of operation has been maintained by the arrival of individuals attracted by the city's international aura, who thus continue to compensate for the great weakness of public subsidies. In this context of a fragmented professional group, weaker professional autonomy seems to be one of the conditions of possibility for the structural autonomy of the Berlin subfield of music venues. The possibility of connecting structural and professional autonomy, as a minority of bookers have been able to do, is based on the city's dominant position in the transnational music field for certain genres, such as electronic music.

In both capitals, bookers trying to regain their professional autonomy without contributing to the rise of economic interests resort to monopolizing professional territories connected to the international circulation of artists. Thus, in analysing forms of professional autonomy as a function of the structural autonomy of a (sub)field, it seems necessary to include "vertical autonomy" in relation to the transnational field. This is particularly the case for highly internationalized objects such as music. The structural autonomy of the fields of live music in Paris and Berlin is thus linked to the interpenetration of the global music and economic fields. The position occupied by these two capital cities within the global music 
position occupée par ces deux capitales au sein du champ musical global, en fonction du capital symbolique accumulé par leurs salles, des mobilisations de leurs agents à l'échelle transnationale, influe

également sur la retraduction d'enjeux à l'échelle locale.

L'hétéronomisation des sous-champs des salles de musique se joue donc certainement à deux niveaux : par rapport au champ économique, mais aussi par rapport au champ musical global. Le cas berlinois en est un exemple frappant. L'autonomie de ses lieux a contribué au rayonnement international de la ville et à la diffusion de formes architecturales et musicales (techno, etc.) emblématiques. Cependant, ces symboles de l'autonomie sont aujourd'hui récupérés par des acteurs économiques dans différentes villes, où les friches exploitées par des entreprises événementielles pratiquent des tarifs élevés et représentent un nouveau pôle d'attractivité économique. En retour, le souschamp musical de Berlin connaît de profondes mutations. Si ces dernières semblent annoncer son hétéronomisation croissante par rapport au champ musical global, elles soulignent plus largement le repositionnement d'une ville, temporairement restée en marge, dans le champ économique global.

\section{Myrtille Picaud \\ Sciences po - Centre d'études européennes (CEE)}

\section{Références bibliographiques}

Аввотt Andrew (1988). The System of professions. An essay on the division of expert labor. Chicago, University of Chicago Press.

ApPaY Béatrice (2005). La Dictature du succès. Le paradoxe de l'autonomie contrôlée et de la précarisation. Paris, L'Harmattan. field, based on the symbolic capital accumulated by their venues and the mobilizations of their agents on a transnational scale, also influences the retranslation of issues at the local level.

The heteronomy of the subfields of music venues plays out on two levels: in relation to the economic field and in relation to the overall field of music. The Berlin case is a striking example. The autonomy of its venues has contributed to the city's international influence and to the spread of its emblematic architectural and music forms (techno, etc.). However, these symbols of autonomy have now been re-appropriated by economic actors in different cities, where industrial buildings and warehouses are exploited by event companies who implement high prices and represent a new pole of economic attractiveness. In turn, Berlin's music subfield is undergoing profound changes. While these changes appear to announce its growing heteronomy with respect to the overall field of music, more broadly they highlight the repositioning within the economic field of a city that had been temporarily sidelined.

Myrtille Picaud

Sciences po - Centre d'études européennes (CEE)

\section{References}

Aввотт Andrew (1988). The System of Professions. An Essay on the Division of Expert Labor. Chicago, University of Chicago Press.

APPAY Béatrice (2005). La Dictature du succès. Le paradoxe de l'autonomie contrôlée et de la précarisation. Paris, L'Harmattan. 
Bourdieu Pierre (1971). « Le marché des biens symboliques ». L'Année sociologique, $22: 49-126$.

Bourdieu Pierre (1992). Les Règles de l'art. Genèse et structure du champ littéraire. Paris, Seuil.

BouRdieu Pierre (1997). Méditations pascaliennes. Paris, Seuil.

Boussard Valérie, Demazlère Didier, Milburn Philip (dir.) (2010). L'Injonction au professionnalisme. Analyses d'une dynamique plurielle. Rennes, Presses Universitaires de Rennes.

BuCHHOLz Larissa (2016). «What is a Global Field ? Rethinking Bourdieu's Field Theory beyond the Nation-State ». The Sociological Review, 64(2) 31-60.

Bureau Marie-Christine, Perrenoud Marc, Shapiro Roberta (dir.) (2009). L'Artiste pluriel, démultiplier l'activité pour vivre de son art. Villeneuve d'Ascq, Septentrion.

Champy Florent (2009). La Sociologie des professions. Paris, Presses Universitaires de France.

Chatterton Paul \& Hollands Robert (2003). Urban Nightscapes. Youth Cultures, Pleasure Spaces and Corporate Power. Londres, Routledge.

Colomb Claire (2012). Staging the New Berlin. Place marketing and the politics of urban reinvention post-1989. New York, Routledge.

Coulangeon Philippe (1999). «Les musiciens de jazz : les chemins de la professionnalisation ». Genèses, 1(36) : 54-68.

DowD Timothy J. (2004). « Concentration and diversity revisited : production logics and the US mainstream recording market, 1940-1990 ». Social Forces, 82(4) : 1411-1455.
BOURDIEU Pierre (1985). "The market of symbolic goods." Translation in English by R. Swyer. Poetics 14(1-2):13-44.

Bourdieu Pierre (1996). The Rules of Art. Genesis and Structure of the Literary Field. English translation by Susan Emanuel. Palo Alto, Stanford University Press.

Bourdieu Pierre (2000). Pascalian Meditations. English translation by Richard Nice. Palo Alto, Stanford University Press.

Boussard Valérie, Demazière Didier, Milburn Philip (eds.) (2010) L'Injonction au professionnalisme. Analyses d'une dynamique plurielle. Rennes, Presses Universitaires de Rennes.

BuchHOLz Larissa (2016). "What is a global field? Rethinking Bourdieu's field theory beyond the nation-state." The Sociological Review, 64(2): 3160 .

Bureau Marie-Christine, Perrenoud Marc, Shapiro Roberta (eds.) (2009) L'Artiste pluriel, démultiplier l'activité pour vivre de son art. Villeneuve d'Ascq, Septentrion.

Champy Florent (2009). La Sociologie des professions. Paris, Presses Universitaires de France.

Chatterton Paul \& Hollands Robert (2003). Urban Nightscapes. Youth Cultures, Pleasure Spaces and Corporate Power. Londres, Routledge

Colomb Claire (2012). Staging the New Berlin. Place Marketing and the Politics of Urban Reinvention Post-1989. New York, Routledge.

CoUlANGEON Philippe (1999). "Les musiciens de jazz : les chemins de la professionnalisation." Genèses, 36: 54-68. 
Duthell-Pessin Catherine \& Ribac François (2017). La Fabrique de la programmation culturelle. Paris, La Dispute.

FreIDSON Eliot (1975). The Profession of Medicine. New York, Dodd and Mead.

FREIDSON Eliot (1986). « Les professions artistiques comme défi à l'analyse sociologique ». Revue française de sociologie, 27(3) : 431-443.

FreIDson Eliot (2001). Professionalism, the Third Logic. On the Practice of Knowledge. Chicago, University of Chicago Press.

FRITH Simon (2007). « Live music matters ». Scottish Music Review, 1(1).

GuiberT Gérôme \& SAGot-Duvauroux Dominique (2014). « Notoriété des artistes et organisation des concerts de musiques actuelles ». In LIZE Wenceslas, NAudier Delphine, Sofio Séverine (dir.), Les Stratèges de la notoriété. Intermédiaires et consécration dans les univers artistiques. Paris, Editions des archives contemporaines : 71-92.

Holt Fabian (2010). "The economy of live music in the digital age ». European Journal of Cultural Studies, 13(2) : 243-261.

INSEE PREMIÈRE (2017). « La culture : une activité capitale ». 1644 : 1-4.

JeAnPIeRRE Laurent \& RouefF Olivier (dir.) (2014). La Culture et ses intermédiaires. Dans les arts, le numérique et les industries créatives. Paris, Éditions des archives contemporaines.

KARPIK Lucien (1995). Les Avocats. Entre l'État, le public et le marché, $X I^{e}-X^{e}$ siècle. Paris, Gallimard.

KRUEger Alan B. (2005). «The Economics of Real Superstars : The Market for Rock Concerts in the Material World ». Journal of Labor Economics, 23(1) : 1-30.
DowD Timothy J. (2004). "Concentration and diversity revisited: production ogics and the US mainstream recording market, 1940-1990." Social Forces, 82(4): 1411-1455.

Dutheil-Pessin Catherine \& Ribac François (2017). La Fabrique de la programmation culturelle. Paris, La Dispute.

Freidson Eliot (2001). Professionalism, the Third Logic. On the Practice of Knowledge. Chicago, University of Chicago Press.

FREIDSON Eliot (1986). "Les professions artistiques comme défi à l'analyse sociologique." Revue française de sociologie, 27(3): 431-443.

Freidson Eliot (1975). The Profession of Medicine. New York, Dodd and Mead.

GuiberT Gérôme \& Sagot-Duvauroux Dominique (2014). "Notoriété des artistes et organisation des concerts de musiques actuelles." In Lizé Wenceslas, Naudier Delphine, Sofio Séverine (eds). Les Stratèges de la notoriété. Intermédiaires et consécration dans les univers artistiques. Paris, Éditions des archives contemporaines: 71-92.

FRITH Simon (2007). "Live music matters." Scottish Music Review, 1(1).

Holt Fabian (2010). "The economy of live music in the digital age." European Journal of Cultural Studies, 13(2): 243-261.

INSEe Première (2017). "La culture: une activité capitale." 1644: 1-4

JeANPIERRE Laurent \& RouefF Olivier (eds.) (2014). La Culture et ses intermédiaires. Dans les arts, le numérique et les industries créatives. Paris, Éditions des archives contemporaines.

KARPIK Lucien (1995). Les Avocats. Entre l'État, le public et le marché, $X I I I^{e}-X X^{e}$ siècle. Paris, Gallimard. 
LIZÉ Wenceslas (2014). "Contraintes, intérêts et dispositions à la pluriactivité chez les intermédiaires des "musiques actuelles" ». In JEANPIERRE Laurent \& ROUEFF Olivier (dir.). La Culture et ses intermédiaires. Dans les arts, le numérique et les industries créatives. Paris, Éditions des archives contemporaines : 125-138

Lizé Wenceslas, NaUdier Delphine, Roueff Olivier (2011). Intermédiaires du travail artistique. À la frontière de l'art et du commerce. Paris, La Documentation française.

LIZÉ Wenceslas \& NAUDIER Delphine (2015). « Intermédiaires, professionnalisation et hétéronomisation des champs artistiques ». In QuiJoux Maxime (dir.), Bourdieu et le travail. Rennes, Presses Universitaires de Rennes : 159-176.

MAuger Gérard (dir.) (2007). Droits d'entrée. Modalités et conditions d'accès aux univers artistiques. Paris, Éditions de la Maison des sciences de l'Homme.

Negus Keith (2002). « The Work of Cultural Intermediaries and the Enduring Distance between Production and Consumption ». Cultural Studies, 4(16) : 501-515.

PICAUD Myrtille (2015). «Les salles de musique à Paris : hiérarchies de légitimité et manières d'entendre les genres musicaux ». Actes de la recherche en sciences sociales, 206-207 : 68-89.

PICAud Myrtille (2017). Mettre la ville en musique (Paris-Berlin). Quand territoires musicaux, urbains et professionnels évoluent de concert. Thèse de doctorat en sociologie. Paris, École des hautes études en sciences sociales.

Regev Motti (2013). Pop-Rock Music : Aesthetic Cosmopolitanism in Late Modernity. Cambridge, Polity Press.
KRUEGER Alan B. (2005). "The economics of real superstars: The market for rock concerts in the material world." Journal of Labor Economics, 23(1): 1-30.

LızÉ Wenceslas (2014). "Contraintes, intérêts et dispositions àla pluriactivité chez les intermédiaires des 'musiques actuelles." In JEANPIERRE Laurent \& Roueff Olivier (eds.). La Culture et ses intermédiaires. Dans les arts, le numérique et les industries créatives. Paris, Éditions des archives contemporaines: 125-138.

LIZÉ Wenceslas, NAUdIER Delphine, ROUEfF Olivier (2011). Intermédiaires $d u$ travail artistique. À la frontière de l'art et du commerce. Paris, La Documentation française.

LIZÉ Wenceslas \& NAUDIER Delphine (2015). "Intermédiaires, professionnalisation et hétéronomisation des champs artistiques." In QuiJoux Maxime (ed.). Bourdieu et le travail. Rennes, Presses Universitaires de Rennes: 159-176.

Mauger Gérard (ed.) (2007). Droits d'entrée. Modalités et conditions d'accès aux univers artistiques. Paris, Éditions de la Maison des sciences de l'homme.

NEGUS Keith (2002). "The Work of Cultural Intermediaries and the Enduring Distance between Production and Consumption." Cultural Studies, 4(16): 501-515.

Picaud Myrtille (2015). "Les salles de musique à Paris: hiérarchies de légitimité et manières d'entendre les genres musicaux." Actes de la recherche en sciences sociales, 206-207: 68-89.

Picaud Myrtille (2017). Mettre la ville en musique (Paris-Berlin). Quand territoires musicaux, urbains et professionnels évoluent de concert. PhD dissertation, Sociology. Paris, École des hautes études en sciences sociales. 
SAPIRO Gisèle (2006). « Les professions intellectuelles entre l'État, l'entrepreneuriat et l'industrie ». Le Mouvement social, 214 : 3-24.

SAPIRO Gisèle (2013). " Le champ est-il national ? La théorie de la différenciation sociale au prisme de l'histoire globale ». Actes de la recherche en sciences sociales, $200: 70-85$

ShoEmAKer Pamela J. \& Vos Timothy (2009). Gatekeeping Theory Londres, Routledge.
Regev Motti (2013). Pop-Rock Music. Aesthetic Cosmopolitanism in Late Modernity. Cambridge, Polity Press.

SAPIRO Gisèle (2006). "Les professions intellectuelles entre l'État, l'entrepreneuriat et l'industrie." Le Mouvement social, 214: 3-24.

SAPIRO Gisèle (2013). "Le champ est-il national ? La théorie de la différenciation sociale au prisme de l'histoire globale." Actes de la recherche en sciences sociales, 200: 70-85.

Shoemaker Pamela J. \& Vos Timothy (2009). Gatekeeping Theory. Londres, Routledge. 